\title{
Upaya Pendayagunaan Limbah Pertanian sebagai Pakan Unggulan Musim Kemarau di Lahan Kering
}

\author{
Markus Miten Kleden, Mariana Nenobais \\ Universitas Nusa Cendana Kupang, mkleden21@gmail.com
}

\begin{abstract}
Limitation of feed and low nutrient consumption in dry season cause a longer period of cattle fattening. The problems can be overcome by applying a cheaper and easier technology namely feed conservation technology. Method applied were extension, training, and mentoring. The result showed that the farmers' participation were very active refers to their present and questiones raised deal with the materials presented. The highly participation also found during the training and mentoring since the feed conservation technology was an innovative activity and high benefit. The activities result were two units of representative model cattle cage due to clean and hygienic aspects, one unit of feed storage, $400 \mathrm{~kg}$ corn straw silage, $300 \mathrm{~kg}$ rice straw ammoniation, and 100 kg concentrate.
\end{abstract}

Keywords: agricultural waste; ammoniation; feed technology; silage.

\begin{abstract}
Abstrak
Kekurangan pakan dan konsumsi nutrien yang rendah oleh ternak selama musim kemarau menyebabkan periode penggemukan sapi menjadi lebih lama. Masalah tersebut dapat diatasi dengan menerapkan teknologi yang murah dan mudah, seperti teknologi konservasi pakan. Metode yang diterapkan dalam kegiatan pengabdian meliputi penyuluhan, pelatihan dan pendampingan. Keterlibatan masyarakat sebagai anggota kelompok tani selama kegiatan penyuluhan sangat tinggi yang tercermin dari banyaknya peserta yang hadir dan pertanyan yang diajukan sebagai respon balik terhadap apa yang telah disampaikan oleh pemateri. Partisipasi aktif mitra juga nampak saat pelatihan dan pendampingan kegiatan konservasi pakan karena merupakan kegiatan baru dan memiliki manfaat tinggi. Hasil yang diperoleh adalah tersedia dua unit kandang contoh yang representatif dari segi kebersihan dan kesehatan, satu unit gudang pakan, silase jerami jagung $400 \mathrm{~kg}$, jerami amoniasi $300 \mathrm{~kg}$ padi dan pakan konsentrat $100 \mathrm{~kg}$.
\end{abstract}

Kata Kunci: limbah pertanian; amoniasi; teknologi pakan; silase 


\section{A. PENDAHULUAN}

Peternakan sebagai bagian integral dari pertanian memegang peranan penting dalam penyediaan protein hewani bagi masyarakat. Pemenuhan kebutuhan protein hewani terkendala setiap tahun karena seiring dengan berjalannya waktu, jumlah pendudukpun semakin bertambah. Pertambahan jumlah penduduk ini menyebabkan kebutuhan protein hewani setiap tahun meningkat. Meskipun demikian, faktor ini sebenarnya merupakan peluang karena permintaan pemenuhan kebutuhan protein hewani terus bertambah.

Kontribusi pertanian termasuk sub sektor peternakan terhadap pendapatan perkapitan masyarakat cukup signifikan. Tingginya kontribusi pendapatan dari usaha ternak sapi, maka petani di Desa Baumata Utara termasuk anggota Kelompok Tani Ternak (KTT) Koleo dan Ikbaun selain menjalankan usaha tani tanaman pangan juga melakukan usaha penggemukan sapi potong. Pelaksanaan usaha penggemukan sapi potong dilakukan dengan cara mengikat/meng-andangkan ternak dengan sistem pemberian pakannya adalah cut and carry. Dominasi wilayah desa yang termasuk dalam kawasan agribisnis dan agrowisata juga menjadi alasan petani untuk mengandangkan ternak sapinya. Jenis pakan yang diberikan terutama rumput alam dan hijauan makanan ternak serta limbah pertanian yang cukup tersedia di desa ini. Walaupun demikian, pemberian konsentrat tidak pernah dilakukan. Hal ini menyebabkan masa penggemukan relatif panjang. Lalus, Lay dan Deno Ratu, 2010 melaporkan bahwa lama penggemukan sapi di Kabupaten Kupang rata-rata 8,33 bulan hingga 2,09 tahun dengan pertambahan berat badan harian maksimal $0,4 \mathrm{~kg}$. Sementara itu, Goa Owa (2010) mengemukakan bahwa masa penggemukan sapi potong di Amarasi Barat adalah 18 bulan untuk mencapai berat $>300 \mathrm{~kg}$ bagi ternak sapi bakalan berumur 18 bulan dengan berat awal $150-180 \mathrm{~kg}$. Hal ini berarti adanya perbaikan teknologi terutama pemberian pakan yang sesuai kualitas dan kuantitasnya dapat memperpendek masa penggemukan, meningkatkan bobot pasar sehingga pendapatan yang akan diperoleh petani pun menjadi lebih tinggi.

Kekurangan pakan selama musim kemarau baik kualitas maupun kuantitas, merupakan masalah utama yang dialami mitra. Alternatif yang dapat dilakukan untuk mengatasi masalah ini adalah bagaimana menjaga kesinambungan usaha melalui upaya penyediaan pakan sehingga ketahanan pakan dapat terwujud. Usaha ketahanan pakan merupakan usaha yang menjadi prioritas dalam mengatasi masalah kekurangan pakan serta meningkatkan pertumbuhan ternak yang bermuara pada peningkatan pendapatan petani. Usaha ketahanan pakan dapat dilakukan melalui kegiatan penyuluhan menyangkut budidaya tanaman pakan dalam areal kebun dan demonstrasi pengolahan pakan hijauan, serta inovasi teknologi suplemen. Melalui kegiatan tersebut diatas diharapkan ketahanan pakan dapat terwujud sehingga masalah kekurangan pakan bagi masyarakat dapat teratasi. Disamping itu juga, masalah konflik antara masyarakat akibat pemanfaatan sumberdaya pakan yang bukan menjadi miliknya dapat dihindari.

Berbagai metoda yang dapat dilakukan dalam pengolahan bahan pakan baik silase, amoniasi dan penyusunan konsentrat. Silase umumnya terbuat dari rumput, namun dapt juga digunakan campuran rumput dan leguminosa seperti daun gamal, daun lamtoro dan jerami kacang tanah (Kleden, 1999; Didiek dkk. 2003; Kleden dan Keban, 2012). Limbah pertanian yang diproduksi petani berupa jerami jagung, jerami padi serta hasil ikutan penggilingan padi. Jerami jagung dapat diolah dalam bentuk silase. Teknologi ini memberikan keuntungan karena jerami 
jagung yang dihasilkan tidak dibuang begitu saja, namun dapat dimanfaatkan sebagai sumberdaya pakan. Disamping jerami jagung, jerami padi yang dihasilkan petani juga dapat dimanfaatkan sebagai sumber pakan. Jerami padi merupakan sumber pakan yang memiliki kualitas rendah karena kandungan protein yang rendah dan tingginya kandungan serat kasar. Jerami padi dapat diolah melalui proses amoniasi sehingga dapat meningkatkan kualitasnya. Penambahan urea sebanyak 4-6 \% dalam proses amoniasi akan meningkatkan kandungan $\mathrm{N}$ jerami padi (McDonald, 1982). Peningkatan $\mathrm{N}$ ini akan meningkatkan aktifitas mikroba rumen sehingga secara umum amoniasi dapat meingkatkan nilai cerna nutrien.

Kualitas jerami padi setelah proses amoniasi mengalami peningkatan kandungan protein kasar. Bata (2008) melaporkan bahwa kandungan protein kasar jerami padi setelah amoniasi sebesar $8,105 \%$ sedangkan yang diamoniasi dan ditambah tetes tebu memiliki kandungan protein sebesar $10,122 \%$. Adanya peningkatan ini memberikan indikasi bahwa jerami padi dapat dimanfaatkan sebagai sumberdaya pakan yang potensial terutama selama musim kemarau yang panjang.

Kegiatan usaha ketahanan pakan dapat terealisasi karena pelaksana kegiatan ini memiliki latar belakang pengetahuan yang memadai serta adanya kesadaran masyarakat dalam menerima dan mentransfer informasi teknologi yang disertai dengan adanya kesepakatan antara ketua kelompok dengan pelaksana kegiatan. Pelaksana kegiatan ini adalah dosen pada Universitas Nusa Cendana yang memiliki kapabilitas ilmu yang sesuai dengan kegiatan yang akan dilakukan. Disamping itu, jarak yang cukup mudah dijangkau sehingga pelaksanaan kegiatan ini dapat terlaksana tepat waktu dan tepat sasaran.

Melalui metode pendekatan dan diikuti dengan kegiatan penyuluhan, pelatihan dan pendampingan kepada anggota mitra. Ada 2 mitra dengan masingmasing mitra terdiri atas 10 orang sehingga secara keseluruhan 20 orang peserta dalam kegiatan ini.

Setelah kegiatan penyuluhan dan diikuti dengan pelatihan dan pendampingan pada mitra dan evaluasi terhadap kegiatan mitra. Mitra dapat melaksanakan apa yang telah diinformasikan terutama menyangkut penerapan teknologi konservasi pakan dengan memanfaatkan limbah pertanian. Secara keseluruhan materi yang diberikan selama kegiatan penyuluhan adalah 1).budidaya tanaman pakan ternak; 2) Manajemen pemberian pakan pada ternak sapi; 3) perkandangan ternak sapi; 4) pengolahan jerami pada dalam bentuk amoniasi; 5) pengolahan pakan limbah jerami jagung sebagai silase; 6) penyusunan konsentrat bagi ternak sapi; 7) dinamika kelompok; dan 8) pembukuan sederhana dalam usaha penggemukan ternak sapi.

\section{Luaran yang diperoleh}

Hasil yang diperoleh dalam kegiatan ini adalah:

Informasi lisan dan tertulis. Tersedianya informasi dalam bentuk tulisan yang diterima saat mengikuti kegiatan penyuluhan. Informasi yang diperoleh diharapkan meningktkan pengetahuan dan dapat digunakan sendiri dalam mengelola sumberdaya pakan untuk memenuhi kebutuhannya maupun informasi yang ada dapat disebarluaskan ke angota masyarakat lainnya sehingga dapat bermanfaat secara komprehensif. Peningkatan pengetahuan akan berpengaruh terhadap perubahan 
perilaku yang lebih baik dalam budidaya ternak sapi.

Partisipasi anggota kelompok. Partisipasi anggota kelompok menjadi salah satu indikator keberadaan kelompok tersebut. Hasil yang diperoleh adalah terlihat adanya partisipasi anggota dalam kegiatan penyuluhan sebagai peserta kegiatan. Jumlah anggota yang hadir merupakan salah satu indikasi kesadaran anggota dalam berorganisasi dan dalam kegiatan pertemuan lainnya. Jumlah anggota yang hadir dan berpartisipasi dalam kegiatan sebesar $95 \%$ dari total anggota yang ditargetkan dalam kegiatan ini. Dari anggota yang hadir sebagian merupakan badan pengurus kelompok sehingga diharapkan adanya kesinambungan informasi yang diberikan dapat disebarluaskan ke anggota lainnya.

Respon dalam pertemuan. Selama proses penyampaian materi oleh nara sumber, terlihat adanya perhatian anggota dalam mengikuti kegiatan penyuluhan. Hal ini terlihat saat hadir mengikuti kegiatan penyuluhan, anggota kelompok datang dengan membawa alat tulis. Informasi yang dianggap dan dirasa penting dicatat. Setelah diberikan materi penyuluhan, terjadi respon balik dari para anggota menyangkut materi penyululuhan yang sudah diberikan. Pertanyaan-pertanyaan yang diberikan anggota kelompok berdasarkan informasi yang sudah diperoleh dan pengalaman yang mereka alami dalam kegiatan pemeliharaan ternak serta dinamika anggota kelompok tani.

Tersedianya dua unit kandang contoh yang memiliki syarat higienis, tersedianya satu unit gudang pakan, tersedianya pakan hasil olahan berupa silase jerami jagung sebanyak $400 \mathrm{~kg}$, jerami padi amoniasi sebanyak $300 \mathrm{~kg}$ dan pakan konsentrat sebanyak $100 \mathrm{~kg}$.

\section{B. PELAKSANAAN DAN METODE}

Pelaksanaan kegiatan ini dilakukan di Desa Baumata Utara Kecamatan Taebenu Kabupaten Kupang tanggal 1 dan 2 Juli 2016 berupa kegiatan penyuluhan dan simulasi, selanjutnya diikuti dengan kegiatan pendampingan hingga 30 September 2016. Materi kegiatan penyuluhan meliputi budidaya tanaman pakan, perkandangan ternak sapi, teknik pengolahan bahan pakan, manajemen pemberian pakan serta pembukuan sederhana dalam pemeliharaan ternak sapi.

Ada dua mitra dengan masing-masing mitra terdiri dari 10 orang sehingga total anggota yang terlibat sebanayal 20 orang. Tingkat pendidikan dari para peserta sangat bervariasi dengan persentasi terbanyak berpendidikan SD $50 \%$, SMP $25 \%$ dan SMA $25 \%$. Meskipun memiliki tingkat pendidikan yang bervariasi, namun partisipasi anggota sangat tinggi baik selama kegiatan penyuluhan maupun kegiatan simulasi serta pendampingan.

Metode pendekatan yang ditawarkan kepada anggota KTT adalah melalui telaahan terhadap masalah aktual yang dialami anggota serta kemampuan dan kemauan yang dimiliki anggota. Kemampaun dan kemauan anggota inilah menjadi dasar penentuan kegiatan yang akan dilakukan karena merupakan fakta yang menjadi faktor penentu keberhasilan pelaksanaan program. Umumnya pelaksanaan program yang berhasil apabila didasarkan pada apa yang miliki dan diinginkan masyarakat. Apa yang ada pada masyarakat menjadi acuan utama dalam mengembangkan program kegiatan IbM baik sumberdaya pakan yang tersedia terutama limbah pertanian dan partisipasi masyarakat dalam mengelola sumberdaya yang dimiliki. 
Peningkatan partisipasi masyarakat sebagai wujud adopsi terhadap inovasi yang diberikan dapat dilihat dari partisipasi masyarakat dalam suatu kegiatan penyuluhan. Kegiatan penyuluhan yang disertai dengan simulasi dan pendampingan perlu dilakukan secara terus menerus. Hal ini bermanfaat dalam membangun kesadaran dalam menjalankan kegiatan usahatani menuju pada peningkatan produksi dan pemenuhan kebutuhan masyarakat.

Pembangunan kandang contoh yang higienis dalam mengatasi pola pemeliharaan ternak yang diikat di sekitar rumah dengan kandang yang kurang higienis dan berpengaruh terhadap kesehatan manusia. Disamping itu juga dilakukan pembangunan gudang pakan sebagai tempat penyimpanan pakan dengan memanfaatkan bahan bangunan yang terdapat di lokasi kegiatan. Pengolahan pakan dalam bentuk silase jerami jagung dan amoniasi jerami padi serta penyusunan konsentrat. Proses pengolahan pakan dalam bentuk silase dan amoniasi dan penyusunan konsentrat adalah sebagai berikut:

\section{Pengolahan silase:}

Langkah-langkah dalam pembuatan silase jerami jagung yang seperti yang dilaporkan peneliti sebelumnya (Didik dkk 2003; Kleden 1999; Kleden dkk 2009 dan Kleden dan Keban 2012) adalah:

Siapkan jerami jagung yang masih segar setelah dipanen hasilnya dalam bentuk jagung muda dan siapkan silo dalam bentuk plastik dan drum bekas. Jerami jagung dicacah dengan ukuran 3-4 cm sehingga mempermudah pemadatan dalam silo. Tambahkan stimulant fermentasi berupa tepung jagung atau dedak halus sebanyak $5 \%$ dari berat hijauan secara berlapis-lapis ke dalam silo. Padatkan hijauan jerami jagung dalam silo dan pengepakan serta dibiarkan selama 3 minggu untuk proses ensilase dan setelah 3 minggu silo dibuka. Evaluasi kualitas dengan pengamatan warna, bau dan memberikannya kepada ternak sapi dalam kandang yang sudah disiapkan sebelumnya.

\section{Pengolahan amoniasi:}

Amoniasi jerami padi dilakukan dengan prosedur yang digambarkan Trisnadewi dkk. (2011) sebagai berikut:

Siapkan jerami padi sejumlah 100 $\mathrm{kg}$, urea sebanyak $4 \mathrm{~kg}$ dilarukan dalam air sebanyak 70 liter (perbandingan air:bahan kering adalah 1:1). Selanjutnya jerami dicacah dengan ukuran 3-5 cm. Potongan jerami padi diletakkan di atas alas terpal/plastik dan diperciki dengan larutan urea hingga semua larutan urea yang disiapkan habis dan tercampur merata dan selanjutnya dimasukkan dalam kantung plastik (silo) dan dipadatkan serta diikat dengan kuat sehingga tidak ada udara yang masuk. Silo ditempatkan di tempat yang teduh dan tidak terkena matahari langsung dan dibiarkan selama 3 minggu. Sesudah itu silo dibuka dan jerami diangin-anginkan selam 1-2 jam ditempat terbuka dan selanjutnya jerami diberikan pada ternak.

\section{Penyusunan konsentrat}

Konsentrat yang digunakan dalam kegiatan ini terdiri dari bahan lokal dengan kandungan protein kasar sebesar $12 \%$. Langkah penyusunan adalah sebagai berikut:

Siapkan tepung jagung $47 \%$, siapkan dedak halus $30 \%$, siapkan bungkil kelapa $22 \%$ dan garam $1 \%$.

Bahan tersebut diatas dicampur dengan cara mencampur bahan yang jumlah proporsi yang paling kecil pertama, paling kecil kedua dan seterusnya hingga semuanya tercapur merata dan siap digunakan sebagai pelengkap sebanyak 0,5 kg per hari 


\section{HASIL DAN PEMBAHASAN}

Pelaksanaan kegiatan IbM telah dilakukan dengan melibatkan anggota kedua kelompok mitra. Sebanyak 20 orang anggota dengan tiap kelompok 10 orang dilibatkan dalam kegiatan IbM. Kegiatan tersebut dibuka oleh kepala Desa Baumata Utara. Inti kegiatan saat itu adalah penyuluhan yang diberikan oleh tim pelaksana. Dalam pelaksanaan kegiatan penyuluhan terjadi interaksi yang merupakan respon dari para anggota. Respon tersebut berupa pertanyaan baik menyangkut budidaya ternak, budidaya pakan dan aspek perkandangan serta analisis ekonomi usaha ternak.

Partisipasi anggota kelompok tani dalam mengikuti kegiatan penyuluhan seperti tertera dalam gambar 1 :

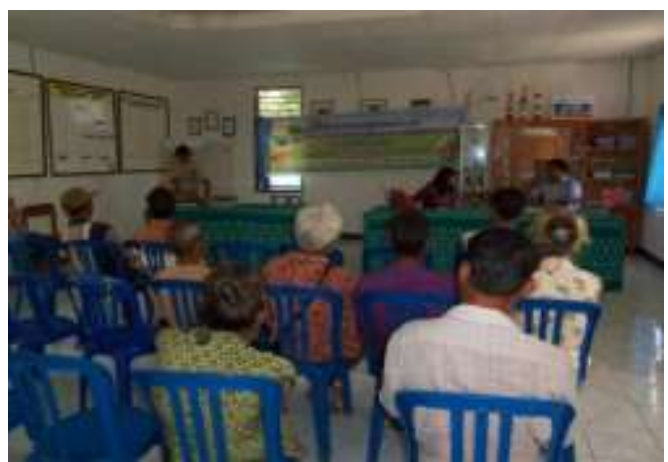

Gambar 1. Partisipasi saat kegiatan penyuluhan.

Respon ini mengindikasikan bahwa keterlibatan anggota dalam kegiatan tersebut termasuk kategori baik. Disamping kegiatan penyuluhan, juga dilakukan kegiatan simulasi terutama bagaimana proses pengawetan pakan baik dalam bentuk segar (silase) maupun dalam bentuk amoniasi serta pembuatan pakan konsentrat. Jumlah bahan dalam simulasi tersebut diperoleh dari anggota kelompok mitra. Mereka menyediakan pakan dalam bentuk rumput segar dan jerami padi dan pakan konsentrat terutama dedak padi. Umumnya partisipasi anggota kelompok sejak awal kegiatan hingga berakhirnya kegiatan tinggi, karena merupakan kegiatan yang menarik. Sebelum kegiatan IbM anggota kelompok hanya diberi materi penyuluhan namun tidak diikuti dengan kegiatan praktek. Kegiatan IbM merupakan kegiatan yang tidak hanya diberi materi penyuluhan namun disertai dengan kegiatan praktek sehingga antusias anggota untuk berpartisipasi secara langsung sangat tinggi. Peningkatan pengetahuan dan keterampilan anggota kelompok peserta kegiatan akan berdampak pada perubahan perilaku dan kesadaran dalam mempertahankan ketersediaan pakan selama penggemukan ternak sapi.

Ketersediaan pakan hasil pengawetan limbah pertanian berupa jerami jagung dan jerami padi. Jerami jagung diawetkan dalam bentuk silase sedangkan jerami padi diawetkan dalam bentuk amoniasi. Silase bertujuan untuk mempertahankan dan atau meningkatkan kualitas hijauan dalam suasana fermentasi terkontrol. Proses pembuatan silase seperti tertera dalam gambar 2.

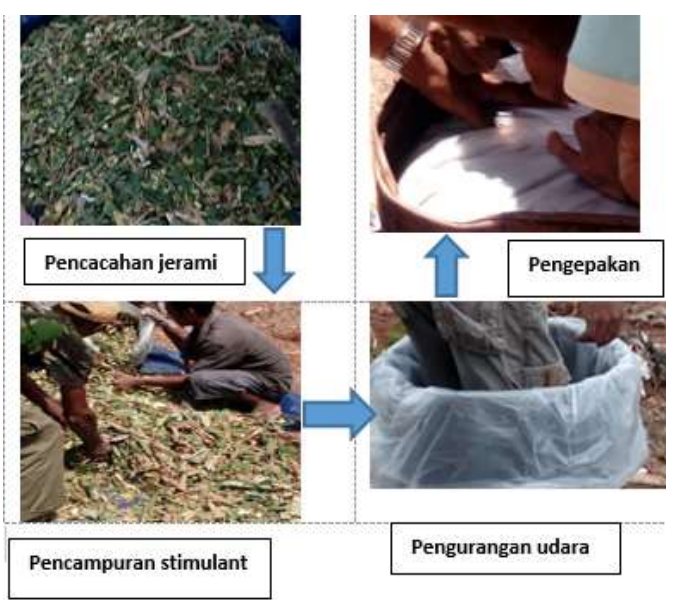

Gambar 2. Proses pembuatan silase

Untuk meningkatkan berkembangnya bakteri dalam proses ensilase, maka ditambahkan sumber karbohidrat yang mudah terfermentasi secara berlapis-lapis ke dalam silo. Penggunaan sumber karbohidrat yang mudah terfermentasi 
umumnya banyak tersedia di tingkat masyarakat sehingga teknologi ini dapat dengan mudah untuk diterapkembangkan. Meskipun terdapat adanya sumber bakteri yang digunakan dalam proses ensilase yaitu inokulant, namun penggunaan sumber karbohidrat yang mudah terfermentasi merupakan cara yang paling tepat dan mudah untuk digunakan.

Selain silase, ada teknologi sederhana lainnya yang dapat diterapkembangkan yaitu teknologi amonias. Amoniasi selain berfungsi untuk mencegah kerusakan jerami padi, juga dapat meningkatkan nilai gizi

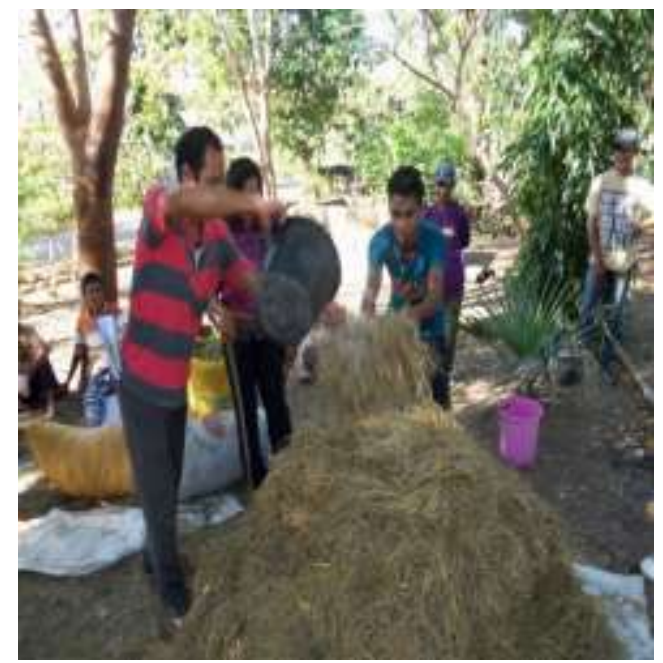

Gambar 3. Pembuatan amoniasi jerami padi

Peningkatan nilai gizi jerami padi hasil amoniasi berupa peningkatan kandungan protein kasar yang disuplay oleh kandungan $\mathrm{N}$ dalam urea. Nitrogen yang terpenetrasi dalam jaringan jerami padi, akan dimanfaatkan sebagai sumber nitrogen dalam proses fermentasi di dalam saluran pencernaan ternak. Hasil fermentasi yang diperoleh dari pemecahan jerami amoniasi adalah senyawa amoniak yang berperanan dalam sintesis asam amino dan protein mikroba sehingga secara umum efisiensi jerami padi sebagai sumber pakan semakin ditingkatkan. Total jerami padi dalam bentuk amoniasi sebanyak $300 \mathrm{~kg}$ sedangkan jerami jagung yang diawetkan dalam bentuk silase sebanyak $400 \mathrm{~kg}$.

Selain amoniasi jerami padi dan silase jerami jagung, dalam kegiatan iuni juga dialatih tentang penyusunan konsentrat. Konsentrat ini penting karena merupakan sumber pakan suplemen terutama selama proses penggemukan ternak. Pakan yang digunakan dalam penyusunan konsentrat adalah bahan pakan yang tersedia disekitar masyarakat sehingga secara umum dapat diterapkan.

Proses pembuatan pembuatan pakan konsentrat seperti tertera dalam gambar 4 .

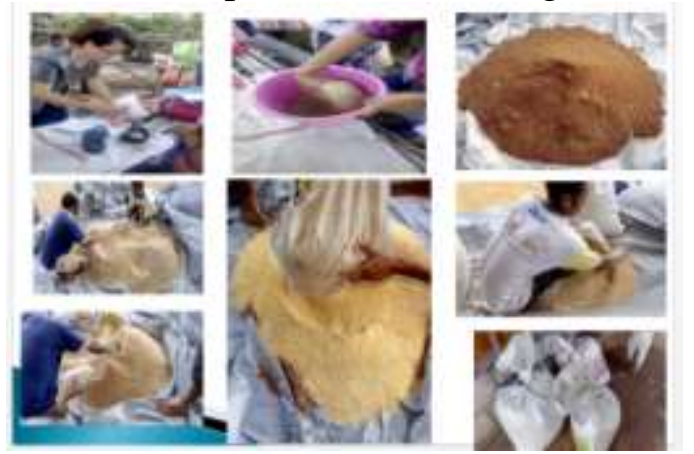

Gambar 4. Pencampuran pakan konsentrat

Bahan pakan yang digunakan dalam penyusunan konsentrat adalah pakan lokal terutama terdiri atas jagung giling, dedak halus dan bungkil kelapa yang disusun dengan kandungan protein kasar sebesar 13 $\%$ sebanyak $100 \mathrm{~kg}$. Proses pencampuran dilakukan dengan cara mencampur bahan pakan yang paling sedikit proporsinya dan terkahir adalah bahan pakan yang paling besar proporsinya

Selama proses pendampingan, keinginan anggota kelompok dalam menyediakan sumberdaya pakan dari limbah pertanian sangat tinggi yang mengindikasikan bahwa pengolahan limbah pertanian menjadi sumberdaya pakan untuk musim tanam berikutnya menjadi perhatian utama. Anggota kelompok tidak akan membiarkan limbah pertanian yang ada menjadi rusak, namun mengolahnya menjadi sumberdaya pakan 
yang dapat digunakan selama musim kemarau. Hal ini menjadi salah satu point utama keberhasilan kegiatan IbM yaitu masyarakat sasaran mampu mengatasi masalah yang ada secara mandiri.

Kemampuan masyarakat dalam mengatasi masalah yang dihadapi secara mandiri menjadi indikator utama peningkatan pendapatan dan kesejahteraan hidup. Kesadaran masyarakat dalam memanfaatkan semua potensi yang dimiliki dapat ditingkatkan melalui penyampaian informasi baik formal maupun informal. Kegiatan IbM merupakan salah satu kegiatan formal yang sangat bermanfaat dalam penyampaian informasi karena merupakan implementasi dari informasi ilmiah yang dihasilkan dari kegiatan penelitian.

Hasil kegiatan yang dilaksanakan menunjukkan bahwa partisipasi masyarakat dalam menerima dan menerapkan informasi yang disampaikan sangat tinggi sehingga kegiatan tersebut memiliki manfaat yang tinggi dan merupakan inovasi yang berhasilguna

\section{PENUTUP}

\section{Simpulan}

Pelaksanaan penyuluhan telah berlangsung dengan tingkat partisipasi anggota tinggi baik dalam proses penyampaian makalah maupun respon balik dalam bentuk pertanyaan-pertanyaan yang disampaikan peserta

Adanya partisipasi diharapkan terjadi peningkatan pengetahuan dan pemahaman anggota kelompok dalam berusaha terutama dalam upaya penyediaan pakan, pengadaan kandang, manajemen usaha serta pemasaran dan analisis ekonomi

Partisipasi anggota dalam pembuatan pakan olahan tinggi saat simulasi pembuatan pakan olahan selama pendampingan karena merupakan teknologi yang relatif mudah untuk dapat diterapkan dengan biaya yang relatif murah dan dapt terjangkau

Tersedianya produk berupa pakan hasil olahan limbah pertanian berupa silase jerami jagung, jerami padi amoniasi, pakan konsentrat dan kandang contoh yang representatif serta gudang pakan.

\section{Saran}

Perbandingan performa ternak yang diberi pakan hasil olahan dan ternak yang tidak diberi pakan secara konvensional dapat diamati apabila kegiatan IbM dapat diteruskan untuk tahun berikutnya sehingga pendanaan kegiatan IbM tidak hanya diberika untuk 1 tahun kegiatan namun untuk 2 tahun kegiatan.

Anggota mitra dapat menerapkan teknologi konservasi pakan dalam budidaya penggemukan ternak sapi dengan memanffatkan hijauan selama musim hujan disaat produksi hijauan tertinggi untuk menjaga kesinambungan suplai pakan selain memanfaatkan produksi limbah pertanian yang ada

\section{Ucapan Terima Kasih}

Penulis menyampaikan terima kasih kepada Direktur Direktorat Riset dan Pengabdian Masyarakat Direkorat Jenderal Penguatan Riset dan Pengembangan, Kementerian Riset, Teknologi dan Pendidikan Tinggi atas bantuan dana sehingga kegiatan ini dapat terlaksana.

\section{DAFTAR PUSTAKA}

Bata, M. 2008. Pengaruh Molases Pada Amoniasi Jerami Padi Menggunakan Urea Terhadap Kecernaan Bahan Kering dan Bahan Organik In Vitro. Agripet : 8(2):15-20

Deno Ratu, M.R., Kleden, M.M. dan Aryanta, M.S. 2007. Peluang dan Kendala Pemberdayaan Potensi 
Peternakan bagi Perbaikan Ekonomi Masyarakat Desa Oeletsala Kecamatan Taebenu, Kabupaten Kupang sebagai Desa Binaan Undana dalam Potensi dan Pengembangan Peternakan Maluku dalam Mendukung Ketahanan Pangan Nasional. Proseding Seminar Nasional, Ambon 2 Maret 2009 hal 200-319 Jurusan Peternakan Fakultas Peternakan Universitas Pattimura Ambon.

Didiek, A.B., Ratnawaty, S. dan Marawali, H.H. 2003. Kelayakan Kompetitif Teknologi Silase dalam Penggemukan Sapi di Kabupaten TTU, Nusa Tenggara Timur. Balai Pengkajian Teknologi Pertanian Nusa Tenggara Timur

Goa, O.O. 2010. Kajian terhadap Program Bantuan Pinjaman Langsung Masyarakat (BPLM) Usaha Ternak Sapi Penggemukan dan Keberlanjutannya di Kecamatan Amarasi Barat, Kabupaten Kupang. Skripsi. Fakultas Peternakan Universitas Nusa Cendana, Kupang.

Kleden, M.M. 1996. Kecernaan In Vivo Hijauan Pakan segar dan Konservasinya pada Kambing. Thesis Program Pasca Sarjana Universitas Gadjah Mada, Yogyakarta

Kleden, M.M. dan Sipahelut, G.M. 2009. Pemanfaatan Nira Lontar dan Urea dalam Proses Ensilase dan Efeknya terhadap Kandungan Serat Kasar dan Total Nutrisi Tercerna rumput Kume (Andropogon Timorensis) dalam Potensi dan Pengembangan Peternakan Maluku dalam Mendukung Ketahanan Pangan Nasional. Proseding Seminar
Nasional, Ambon 2 Maret 2009 hal 143-161 Jurusan Peternakan Fakultas Peternakan Universitas Pattimura Ambon.

Kleden, M.M., Sarifudin, K. dan Manu, A.E. 2009. Suplementasi Pakan Dan Cobalt/Zeolit Alam Aktif (Co/Zaa) Untuk Optimalisasi Fungsi Rumen Dan Peningkatan Pertumbuhan Ternak Kambing Lokal Sebagai Upaya Pemenuhan Kebutuhan Protein Hewani. Laporan Penelitian Fakultas Peternakan Universitas Nusa Cendana, Kupang.

Kleden, M.M. dan Keban, A. 2012. Nilai Gizi dan Nilai Cerna Nutrien Secara In Vitro Silase Campuran rumput Gajah-Daun Gamal yang Ditambahkan Tepung Bonggol Pisang. Seminar Nasional BPTP Naibonat Kupang Nusa Tenggara Timur

Lalus, M.F. dan Deno Ratu, M.R. 2009. Pengembangan Sistem Pemeliharaan Ternak Sapi Bali (Modifikasi Sistem Tradisional Timor) Menghadapi Target Kecukupan Daging Nasional 2010 di Kabupaten Kupang. Laporan Penelitian Fakultas Peternakan Universitas Nusa Cendana, Kupang.

McDonald, P., Edwards, R.A. and Greenhalg, J.P.D., 2002. Animal Nutrition. sixth Ed. Prentice hall. Gosport. London. Pp : 427-428.

Trisnadewi, A.A.A.S., Sumardani, N.L.G., Tanama Putri, B.R., Cakra, I G.L.O. dan Aryani, I G.A.I. 2011. Peningkatan Kualitas Jerami Padi Melalui Penerapan Teknologi Amoniasi Urea sebagai Pakan Sapi Berkualitas di Desa Bebalang Kabupaten Bangli. Udayana Mengabdi 10(2):72-74 